\title{
A key to the species of Keetia (Rubiaceae - Vanguerieae) in West Africa, with three new, threatened species from Guinea and Ivory Coast
}

\author{
Martin Cheek ${ }^{1}$ D, Sekou Magassouba ${ }^{2}$, Denise Molmou ${ }^{2}$, Tokpa Seny Doré2 ${ }^{2}$ Charlotte Couch ${ }^{1,2}$, \\ Shigeo Yasuda ${ }^{1}$, Charlie Gore ${ }^{3}$, Amy Guest ${ }^{3}$, Aurelie Grall ${ }^{1}$, Isabel Larridon ${ }^{1}$, Isabelle H. Bousquet ${ }^{4}$, \\ Bella Ganatra ${ }^{5}$ \& George Gosline ${ }^{1}$
}

Summary. Keetia susu Cheek and K. futa Cheek from the Republic of Guinea, and K. abouabou Cheek from Ivory Coast are described here. Each species is assessed using the IUCN standard as, respectively, Vulnerable, Endangered and Critically Endangered. Each species is illustrated and mapped. A key to the 16 species of Keetia in West Africa (Senegal to Benin) is provided. The number of species of Keetia currently accepted is now known to total 35.

Key Words. Conservation, extinction, stage-dependent heteromorphy, white sand.

\section{Introduction}

Keetia E. Phillips was segregated from Canthium by Bridson (1985, 1986). Restricted to Africa, this genus of about 32 species (http://www.plantsoftheworldonline.org/ ?f=accepted_names\%2Chas_images\&q=Keetia), are mainly forest climbers, distinguished from similar Canthoid genera in west Africa by their pyrenes with a fully or partly-defined lid-like area around a central crest (Bridson 1986). In a phylogenetic analysis of the tribe based on morphology, nuclear ribosomal ITS and chloroplast trmT-F sequences, Lantz \& Bremer (2004), found that Keetia was monophyletic with strong support.

Bridson's (1986) account of Keetia was preparatory to treatments of the Vanguerieae for the Flora of Tropical East Africa (Bridson \& Verdcourt 1991) and Flora Zambesiaca (Bridson 1998). Pressed to deliver these, she stated that she could not dedicate sufficient time to a comprehensive revision of the species of Keetia outside these areas (Bridson 1986). "Full revision of Keetia for the whole of Africa was not possible because the large number of taxa involved in West Africa, the Zaire basin and Angola and the complex nature of some species would have caused an unacceptable delay in completion of some of the above Floras." (Bridson 1986). Further "A large number of new species remain to be described." Several of these new species were indicated by Bridson (1986), and other new species by her arrangement of specimens in folders that she annotated in the Kew Herbarium. One of these species was later taken up and published by Jongkind (2002) as K. bridsoniae Jongkind. In the same paper, Jongkind discovered and published $K$. obovata Jongkind based on material not seen by Bridson. Based on new material, additional new species of Keetia have been published by Bridson \& Robbrecht (1993), Bridson (1994), Cheek (2006) and Lachenaud et al. (2017).

Recent collections of herbarium specimens from surveys of forests in Guinea in connection with the "Important Plant Areas of the Republic of Guinea" Darwin Initiative project (http://www.herbierguinee.org/ztipsdarwin.html) have exposed the presence of three undescribed species of Keetia from Guinea and Ivory Coast: all of which are threatened in terms of the IUCN 2012 categories and criteria. Here they are formally circumscribed and named, so that their conservation assessments can be accepted by IUCN, and so that these species can then be incorporated in the data-set being used to select the Important Plant Areas of Guinea (Darbyshire, continuously updated), using the revised IPA criteria of Darbyshire et al. (2017).

In this paper we build on the work of Bridson (1986, 1994) and describe three further new species from Guinea and Ivory Coast.

Following decades of relative inactivity in Republic of Guinea, in recent years there has been a

\footnotetext{
Accepted for publication 25 September 2018. Published online 22 November 2018

1 Royal Botanic Gardens, Kew, Richmond, Surrey, TW9, 3AE, UK. e-mail: m.cheek@kew.org

2 Herbier National de Guinée, Université Gamal Abdel Nasser, Conakry, Guinea.

3 Department of Biological and Medical Sciences, Oxford Brookes University, Headington Campus, Oxford, OX3, OBP, UK.

478 Cleveland Gardens, Barnes, SW13 OAH, UK.

54 Merricks Court, 71 Temple Sheen Rd, London, SW14 7RS, UK.
} 
dramatic rise in the publication of new discoveries of plant species. Many of these were discovered in connection with baseline studies for the proposed iron ore mine in the Simandou range (see under Keetia futa, below). Elsewhere in Guinea, recently discovered new species are: Eriocaulon cryptocephalum S. M. Phillips \& Mesterházy (Eriocaulaceae) (Phillips \& Mesterházy 2015), Inversodicraea pepehabai Cheek (Podostemaceae) (Cheek \& Haba 2016), Napoleonea alata Jongkind (Lecythidaceae) (Prance \& Jongkind 2015), Talbotiella cheekii van der Burgt (Leguminosae) (van der Burgt et al. 2018). In another case, Mesanthemum tuberosum Lecomte (Eriocaulaceae), endemic to Guinea but previously synonymised, was resurrected (Phillips et al. 2018). Just over the border in Mali, Calophyllum africanum Cheek (Calophyllaceae) (Cheek \& Luke 2016) was recently found and in Ivory Coast Macropodiella cussetiana Cheek (Podostemaceae) (Cheek \& Ameka 2016). Even two new genera have come to light in Guinea, Karima Cheek \& Riina (Euphorbiaceae) (Cheek et al. 2016) and Kindia Cheek (Rubiaceae) (Cheek et al. 2018b).

\section{Materials and Methods}

Names of species and authors follow IPNI (continuously updated). Herbarium material was examined with a Leica Wild M8 dissecting binocular microscope fitted with an eyepiece graticule measuring in units of $0.025 \mathrm{~mm}$ at maximum magnification. The drawing was made with the same equipment with a Leica 308700 camera lucida attachment. Pyrenes were characterised for each species, where available, by boiling selected ripe fruits for several minutes in water until the flesh softened and could be removed. Finally, a toothbrush was used to clean the exposed pyrene surface. Specimens were inspected from the following herbaria: BM, FHO, HNG, K, P. The format of the description follows those in other papers describing new species of Keetia, e.g. Cheek (2006). All specimens seen are indicated "!"

The conservation assessment follows the IUCN (2012) standard. Herbarium codes follow Index Herbariorum (Thiers, continuously updated). The key to species below is for use with herbarium specimens and is based on that of Hawthorne \& Jongkind (2006).

\section{Taxonomic Treatment}

\section{Key to the species of Keetia in West Africa (Senegal to Benin)}

1. Leaf bases on main axis rounded to cuneate. Leafy stems and petioles glabrous, or with hairs appressed, or with hairs

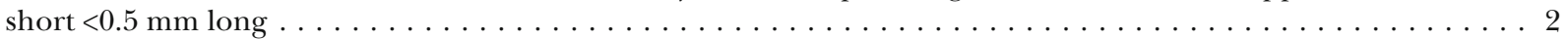
Leaf bases on main axis cordate. Leafy stems and petioles with long, stiff more or less erect hairs $>1.5 \mathrm{~mm}$

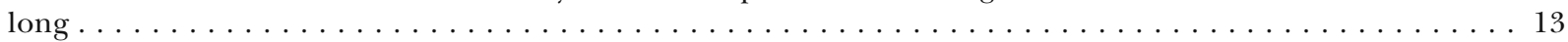

2. Tertiary nerves of leaf-blade conspicuously scalariform $\ldots \ldots \ldots \ldots \ldots \ldots \ldots \ldots$

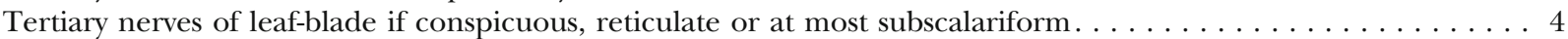

3. Leaves $>3 \mathrm{~cm}$ wide; stipules $>1 \mathrm{~cm}$ long $\ldots \ldots \ldots \ldots \ldots \ldots \ldots \ldots$

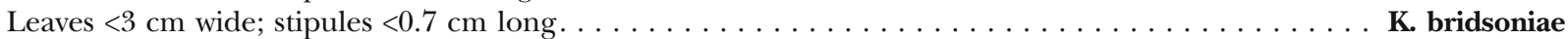

4. Leaves hairy on lower surface, on both veins and inter-vein areas $\ldots \ldots \ldots \ldots$ Leaves glabrous on lower surface, or if hairy, only on the midrib and secondary nerves $\ldots \ldots \ldots$

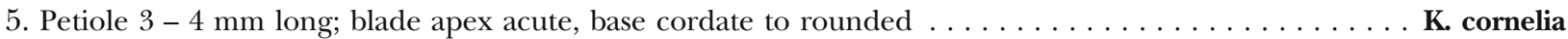
Petiole $6-8 \mathrm{~mm}$ long; blade apex acuminate, base cuneate $\ldots \ldots \ldots \ldots \ldots \ldots \ldots \ldots \ldots$. $\ldots \ldots$ tenuiflora s.l.

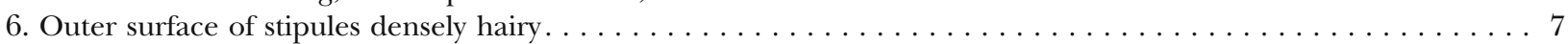

Outer surface of stipules glabrous, or with only a few hairs. $\ldots \ldots \ldots \ldots \ldots \ldots$

7. Leaves drying red-brown; tertiary nerves subscalariform $\ldots \ldots \ldots \ldots \ldots \ldots \ldots$ rubens

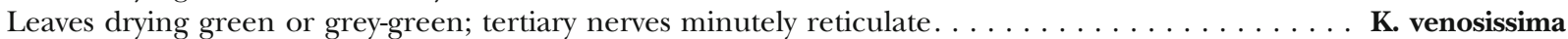

8. Leaf blade obovate or oblong-elliptic, apex rounded $\ldots \ldots \ldots \ldots \ldots \ldots \ldots \ldots \ldots$

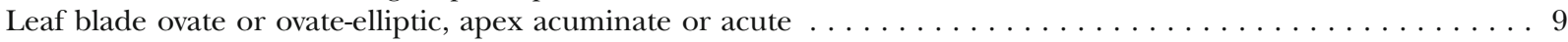

9. Stipules ovate, $>7 \mathrm{~mm}$ wide, apex lacking arista; petiole hairs patent, $>1.5 \mathrm{~mm} \operatorname{long} \ldots \ldots \ldots$ $\ldots \ldots \ldots \ldots \ldots \ldots \ldots \ldots \ldots \ldots \ldots \ldots \ldots \ldots \ldots \ldots$ molundensis var. molundensis

Stipules triangular, $<5 \mathrm{~mm}$ wide, aristate; petiole glabrous $\ldots \ldots \ldots \ldots \ldots$

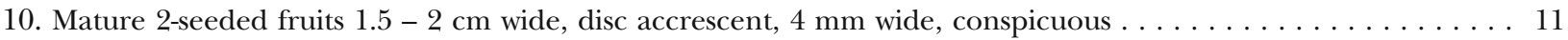

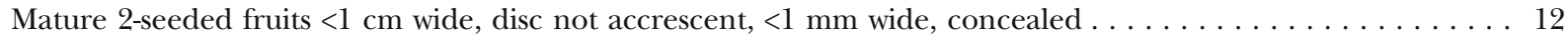

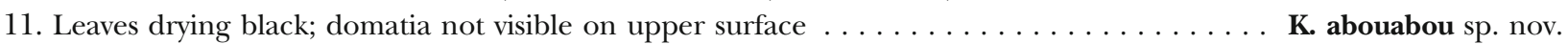
Leaves drying green; domatia visible on upper surface $\ldots \ldots \ldots \ldots \ldots \ldots \ldots \ldots$. susu sp. nov.

12. Pedicel densely pubescent; domatia present; leaves with tertiary nerves inconspicuous. . . . . . . . . . K. mannii Pedicel glabrous or sparsely hairy; domatia absent; leaves with tertiary nerves conspicuous, black. . . K. multiflora

13. Leaves with $5-7$ secondary nerves on each side of the midrib; stem hairs red or dark brown . . . . . . . 14 
Leaves with 8 - 10 secondary nerves on each side of the midrib; stem hairs white $\ldots \ldots \ldots$. . . K. rufivillosa

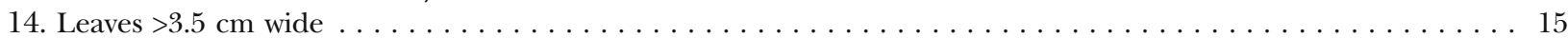
Leaves $<3.5 \mathrm{~cm}$ wide $\ldots \ldots \ldots \ldots \ldots \ldots \ldots \ldots \ldots \ldots \ldots \ldots \ldots$

15. Stem hollow, with ants; tertiary nerves of leaf blades forming a dense reticulate pattern with hundreds of minute

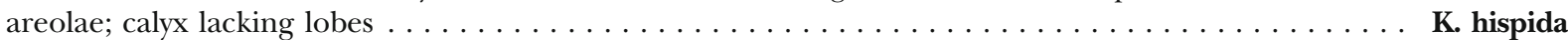
Stem solid, without ants; tertiary nerves of leaf blades sparse, reticulate pattern absent; calyx with lobes . . . . K. futa sp. nov.

Keetia susu Cheek sp. nov. Type: Guinea-Conakry, Kindia Prefecture, Grandes Chutes, Forêt Classé, $9^{\circ} 54^{\prime} 06.3 " \mathrm{~N}, 13^{\circ} 5^{\prime} 40.6^{\prime \prime} \mathrm{W}$, fl.fr. 9 Oct. 2016, Cheek $\xi^{\circ}$ van der Burgt 18644 (holotype HNG!; isotypes BR!, EA!, K!, US!).

http:/ /www.ipni.org/urn:lsid:ipni.org:names:60477041-2

Evergreen small tree or shrub, initially scandent, 2.5-6 m tall. Trunk 3-8 cm in diam., bark grey-brown. Primary stems scandent with occasional reflexed pairs of leafy secondary, brachyblasts (short plagiotropic or spur) shoots (Fig. 1A). Leafy stems glossy green, glabrous, drying glossy purple, lacking lenticels in the distal internodes, internodes $(1.7-(2.0-4.8(-7.5) \mathrm{cm} \times(0.1-) 0.2-0.4(-$ $0.5) \mathrm{mm}$. Leaves distichous, not dimorphic, opposite and equal at each node and between nodes, thinly leathery, glabrous, apart from the domatia; blades drying pale to mid green on both surfaces, glossy green when alive, midrib pale yellow, raised on adaxial surface, secondary nerves also pale yellow; elliptic-oblong or ovate-elliptic, $(4.7-) 5.2-10.3(-11.6) \times 2.1-4.8(-6.8) \mathrm{cm}$, acumen (0.2 -) $0.4-0.7(-1.1) \mathrm{cm}$ long, base obtuse to acute, usually asymmetric and decurrent on petiole, secondary nerves $4-6(-7)$ on each side of the midrib, arising at c. $60^{\circ}$ from the midrib, curving upwards and sometimes uniting with the nerve above. Tertiary nerves inconspicuous. Domatia elliptic-oblong, $1.2 \times 0.7-1 \mathrm{~mm}$, inserted over the surface of the subtending secondary nerve, with c. 80 red bristle hairs inserted around the rim, directed centripetally: on upper surface raised, glossy, pale green. Margin thickened, revolute. Petioles canaliculate, the distal part with wings decurrent from the blade, patent, gradually contracting towards the stem, (0.4-) $0.6-1$ (1.6) $\mathrm{cm}$ long, $0.1 \mathrm{~cm}$ wide, glabrous.

Stipules free, glabrous, at stem apex aristate from a broad base, often with translucent yellow beads of colleter exudate when dry; developed stipules of node below \pm triangular $4-5.5 \times 3.5-4.5 \mathrm{~mm}$ flat, except for the keel-like, laterally leaning thickened arista, caducous, falling at second or third node from stem apex, leaving a bright white scar across the node. Inflorescences glabrous (Fig. 2A), axillary on long plagiotropic branches, held above the stem, in $4-6$ successive nodes beginning $1(-2)$ nodes below stem apex; anthesis \pm simultaneously at $1-4$ nodes, each $20-$ 30-flowered, forming globose heads $3.5-5 \mathrm{~cm}$ diam.
(Fig. 2A). Peduncles $6-10 \mathrm{~mm}$, with a pair of triangular, concave bracts $2-5 \mathrm{~mm}$ below the apex, bracts c. $2 \times 1.5$ $\mathrm{mm}$, midrib keeled, persistent; branches two, equal, 2 $7 \mathrm{~mm}$ long, with $2-3$ pairs of subapical bracteoles c. $1 \mathrm{~mm}$ long, each branch sometimes further forked, or terminating in a fascicle of $10-15$ flowers. Inflorescences 1 - 5-fruited, axes with thinly scattered simple hairs $1 \mathrm{~mm}$ long (Fig. 1F). Flowers with pedicels $4-5 \mathrm{~mm}$ long, $0.2-0.3 \mathrm{~mm}$ wide, glabrous at anthesis. Calyxhypanthium obconical with a pair of shallow opposite longitudinal grooves, $1 \times 1-1.5 \mathrm{~mm}$, calyx tube shortly cylindrical, $0.25 \mathrm{~mm}$ long; teeth 5 , triangular, slightly incurved, $0.5 \times 0.25 \mathrm{~mm}$, the dorsal apex with $3-5$ erect, red simple hairs $0.1-0.15 \mathrm{~mm}$ long (Fig. 2E). Corolla cylindrical in bud $4.5-5.5 \times 2-2.5 \mathrm{~mm}$, distal $1 / 4$ slightly wider than proximal part, apex rounded; at anthesis green-white, tube $4 \times 2 \mathrm{~mm}$, lobes 5 , valvate, reflexed, $2 \times 1.5 \mathrm{~mm}$, mouth with exserted, moniliform white hairs $0.7-1.1 \mathrm{~mm}$ long (Fig. 2K); inner surface glabrous from base to a ring of translucent deflexed hairs c. $1.5 \mathrm{~mm}$ long, inserted c. $2 \mathrm{~mm}$ above base (Fig. 2C, J), above the ring sparsely hairy, the hairs straggling-subappressed, moniliform. Stamens 5, inserted just below the mouth, erect, filaments flat, $0.5 \times 0.3 \mathrm{~mm}$ (Fig. $2 \mathrm{H}$ ); anthers oblanceolate-sagittate, $2 \times 1 \mathrm{~mm}$ (Fig. 2G, H), subbasifixed, the two splayed bases acute, with a short tail $0.1-0.3 \mathrm{~mm}$ long. Disc convex, puberulent, hairs $0.1-0.2 \mathrm{~mm}$ long, densest and longest around the style base (Fig. 2D, F). Style $7-8 \mathrm{~mm}$ long, $0.25 \mathrm{~mm}$ wide, terete, tapered at the apex towards an obconical head or receptaculum pollinis, c. $1 \times 0.75$ mm. Fruit ripening jet black, glossy, from green; fleshy, (13-) $15-17 \times(15-) 18-20 \times 11-13 \mathrm{~mm}$, the two carpels united along their length but divided by a longitudinal groove on each side (Fig. 2L), apex truncate, disc massively accrescent, grey, corky (5-) $7-8 \mathrm{~mm}$ diam., calyx teeth persistent (Fig. 1G); base slightly cordate; 1-seeded fruits (by abortion), frequent, ovoid-elliptic, asymmetric, c. $16 \times 12 \mathrm{~mm}$. Pyrene dark brown, woody subellipsoid, $1.5 \times 1 \times 1$ $\mathrm{cm}$, the surface with low, irregular, elliptic raised areas c. $1.5 \mathrm{~mm}$ long. Lid on ventral face, angled at c. $45^{\circ}$, from near apex to $2 / 5$ the distance to base of pyrene, rounded-quadrate, $7 \mathrm{~mm}$ wide, with a marked fissure along the midline. Lacking ridges, crests or other ornamentation. Figs $1-3$. 
RECOGNITION. Differs from Keetia abouabou in the winged petiole apex (vs not winged), dried leaf blade green, midrib yellow (not both black); domatia visible on abaxial blade (not invisible); brachyblasts reflexed (not erect); post-anthetic inflorescence hairy (not glabrous). See Table 1.

DISTRIBUTION. Guinea-Conakry, Coyah and Kindia Prefectures including Mt Gangan and Kounounkan, the southern extension of the Fouta Djalon. Map 1. SPECIMENS EXAMINED. GUINÉE (CONAKRY). Mt Gangan, Kindia, Grandes Chutes, 9 $5^{\prime} 46.3^{\prime \prime N}, 13^{\circ} 5^{\prime} 40.6^{\prime \prime} \mathrm{W}$, 148 m, fl. fr., 9 Oct. 2016, Cheek 18644 (HNG!, K!); Kindia to Telimele, sandstone bowal, $10^{\circ} 9^{\prime} 41.6^{\prime \prime} \mathrm{N}$, $12^{\circ} 52.2^{\prime \prime W}, 400 \mathrm{~m}$, fr. 18 June 2016, Cheek 18521 (HNG!, K!); Kindia to Telimele, sandstone rock outcrops west of road, $10^{\circ} 9^{\prime} 09.8^{\prime \prime} \mathrm{N}, 12^{\circ} 51^{\prime} 26.9^{\prime \prime} \mathrm{W}$, 194 m, fr. 4 Feb. 2016, Cheek 18327 (HNG!, K!); Mt Gnonkaoneh, NE of Mayon Khoure village which is $\mathrm{W}$ of Kindia to Telimele rd, $10^{\circ} 7^{\prime} 02.2^{\prime \prime} \mathrm{N}$, $12^{\circ} 52^{\prime} 02.6^{\prime \prime} \mathrm{W}, 432 \mathrm{~m}$, fr. 19 June 2016, Cheek 18533 (HNG!, K!); $\mathrm{N}$ of Mayon Khoure, $10^{\circ} 7^{\prime} 23.6^{\prime \prime} \mathrm{N}$, $12^{\circ} 52^{\prime} 6.6^{\prime \prime} \mathrm{W}, 148 \mathrm{~m}$, fl. fr. 30 Sept. 2016, Cheek 18597 (K!); Coyah: Near Kouria, Coyah to Kindia rd, beyond town at foot of table $\mathrm{mts}$, along and upstream to forest patch $18,9^{\circ} 45^{\prime} 29.0^{\prime \prime} \mathrm{N}$, $13^{\circ} 18^{\prime} 16.7^{\prime \prime W}, 188$ m, fr. 28 Sept. 2015, Cheek 18182 (HNG!, K!); Near Kouria, Coyah to Kindia rd, forest patch $17,9^{\circ} 46^{\prime} 40.7^{\prime \prime N}, 13^{\circ} 16^{\prime} 42.0^{\prime \prime}, 460 \mathrm{~m}, 12$ Oct. 2016, Diallo Almamy 32 (HNG!, K!, WAG!); Footpath from Domboyah (after Coyah) to Saliyah, $9^{\circ} 43^{\prime} 46.0^{\prime \prime} \mathrm{N}, 13^{\circ} 17^{\prime} 28.2^{\prime \prime} \mathrm{W}, 250 \mathrm{~m}, 28$ Sept. 2015, Cheek 18154 (HNG!, K!); Kounounkan, Mont Dalonia Ghia, southern part of Plateau de Benna, $5 \mathrm{~km}$ E of Gbereboun Village, above Forêt Classée de Kounounkan, 9॰33'07.8"N, 1251'43.0"W, 1050 m, fr. 25 Sept. 2016, van der Burgt 2019 (BR!, HNG!, K!, MO!, P!, WAG!); Sandstone hill range SW of Plateau de Benna, 2.5 km SW of Gbara Village, Forêt Classée de Kounounkan, 9॰31'20.1"N, 1256'57.3"W, 540 m, fr. 28 Sept. 2016, Diallo Almamy 4 (HNG!, K!).

HABITAT \& ECOLOGY. Relict lowland evergreen forest and secondary woodland fragments on the sides of sandstone table mountains. $200-870 \mathrm{~m}$ alt.

CONSERVATION STATUS. The surviving islands of forest and woodland in Coyah Prefecture from which Keetia susu is known are steadily being degraded by woodcutting for timber for construction, firewood, and charcoal production and also suffer from contraction as a result of the cycles of slash and burn to clear the fallow thickets that surround them to prepare for cultivation of rice and other crops (Cheek pers. obs. 2015 - 2016).

Keetia susu is less threatened at its sites in the Mt Gangan area of Kindia Prefecture than elsewhere. Here it occurs as scattered shrubs or small trees in fissures in the otherwise bare sandstone steps. Nevertheless, it is among the small trees that are cut for firewood and the manufacture of charcoal to supply cooking fuel to Kindia (Cheek pers. obs. 2015 - 2016). Using Geocat (Bachman et al. 2011), we calculated the extent of occurrence (EOO) of this taxon as 1,910.5 $\mathrm{km}^{2}$, and the area of occurrence (AOO) as $28 \mathrm{~km}^{2}$. Both metrics equate to an Endangered assessment under criterion B. However, eight distinct locations can be recognised, signifying an assessment of Vulnerable, VU B1+B2a,b(iii) given the widespread threats present at all known sites of deforestation for charcoal production. Additionally, fires are set in this area, and flammability/resistance of the species is not quantified, therefore this is a potential concern. No sites for this species are in protected areas.

ETYMOLOGY. The species is named for the Susu people, since all plants seen are in Susu-speaking areas. The hope is that the Susu will ensure that their species does not become extinct.

NOTES. While identifying specimens collected in recent surveys in Guinea-Conakry of remnants of forest from the sandstone table mountains in the southern extension of the Futa Djalon highlands, material came to light that fitted no species in either Hepper (1963), Bridson (1986), Hawthorne \& Jongkind (2006) or Lisowski (2009). Initially it was matched with and thought to be conspecific with material from Ivory Coast named in this paper as Keetia abouabou (see below), despite the large geographical and ecological disjunctions. Both taxa share the massive fruits, with disproportionately large accrescent discs, large, open pit-like domatia, inconspicuous tertiary nerves and glabrous leaves and stems, that separate them both from $K$. mannii (Hiern) Bridson. However, the inflorescences of the Guinea material, here named Keetia susu, have thick, multicellular hairs (not glabrous) together with sufficient other diagnostic characters (see Table 1) to justify species rank. It is remarkable that this tree, not infrequent in forest remnants near some major towns, has remained uncollected for so long.

THE HABIT OF KEETIA SUSU. Observations of about 20 mature individuals of Keetia susu in the region of Mayon Khouré during October 2015 and June 2016 and in Grandes Chutes Forêt Classé (Oct. 2016) (Cheek pers. obs.) indicate that this species occurs as scattered individuals always in association and beneath an isolated small tree of another species, such as Vitex ferruginea (Cheek 18532), usually growing in fissures in the sandstone that forms flat bowal areas or the steep, step-like slopes of the low table mountains.

Keekia susu varies in habit according to its stage in life. It appears to establish beneath trees, perhaps from bird-deposited pyrenes, and to begin life establishing as a shrub, growing to the height of $\mathrm{c}$. $1.5 \mathrm{~m}$. From this stage, long, erect, extension shoots of several metres length are produced. These ascend through the branches of the tree above; 


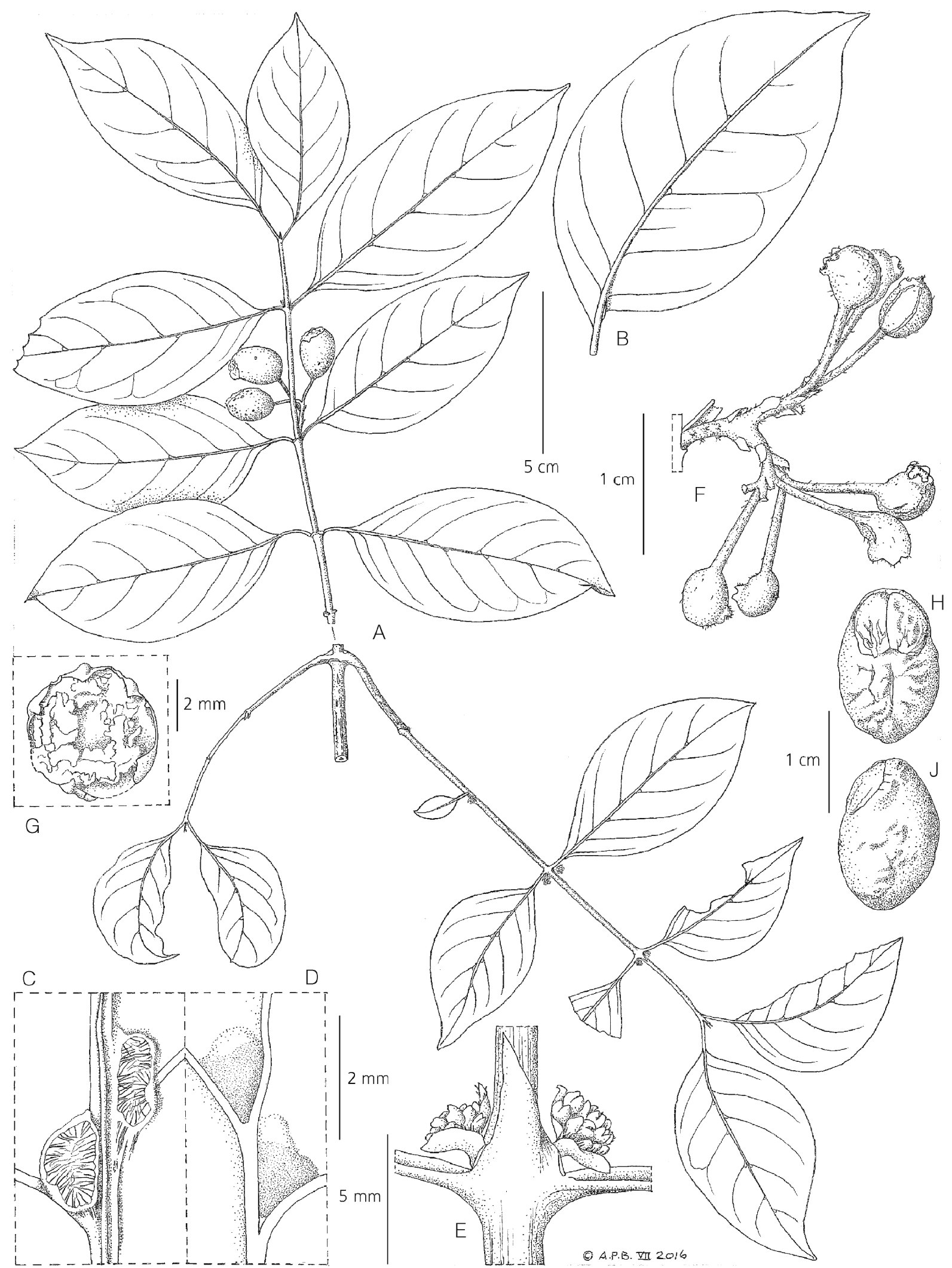

Fig. 1. Keetia susu. A habit, fruiting stem, with reflexed secondary (short plagiotropic or spur) shoots; B leaf-blade, asymmetric base, abaxial surface; $C$ domatia, abaxial surface; $D$ adaxial surface of $C$; $E$ node from reflexed spur shoot in $A$, showing stipule and axillary inflorescence buds; $\mathrm{F}$ post-anthetic flowers (immature infructescences); $\mathrm{G}$ fruiting disc, showing corky surface; $\mathrm{H}$ pyrene, ventral surface; J pyrene, side view. A, C - E from Cheek 18182; B, F - J from Cheek 18327. DRAWN BY ANDREW BROWN. 


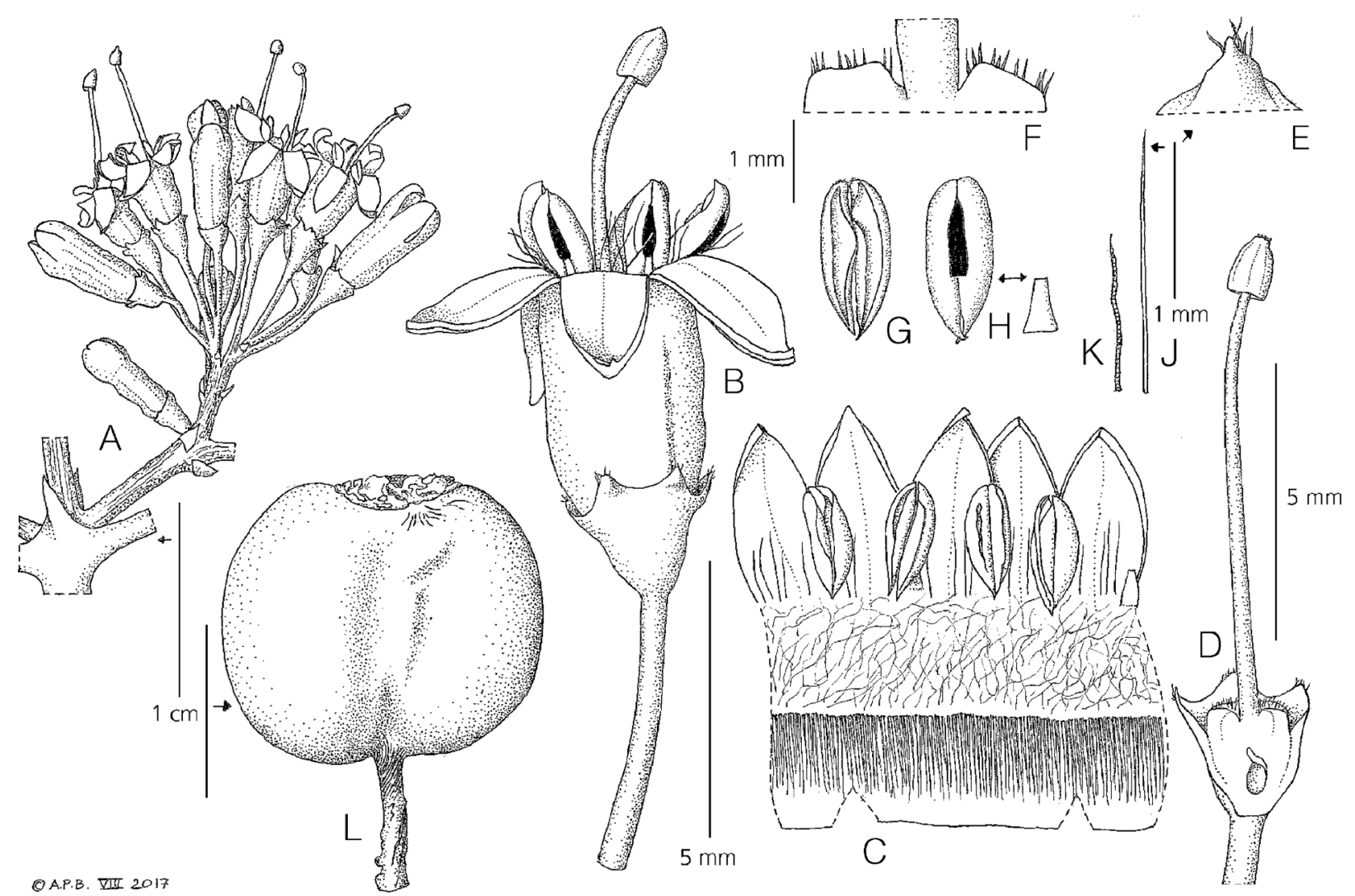

Fig. 2. Keetia susu. A inflorescence; B flower, side view; C corolla opened out, inner surface; D flower with corolla removed, longitudinal section through ovary-calyx; $\mathrm{E}$ calyx lobe apex, external surface; $\mathrm{F}$ transverse section of disc and style base; $\mathrm{G}$ anther, dorsal surface; $\mathrm{H}$ anther ventral surface, with filament; J deflexed hair from base of corolla tube; $\mathrm{K}$ moniliform hair from base of corolla lobes; $\mathrm{L}$ two-seeded fruit, side view. A - K from Cheek 18644; L from van der Burgt 2019. DRAWN BY ANDREW BROWN.

assisted by pairs of reflexed short plagiotropic shoots or spur-shoots. The Keetia susu individuals finally become free-standing trees, and approach or exceed the size of the tree under which they established (Cheek pers. obs. Kindia, June 2015).

Keetia abouabou Cheek sp. nov. Type: Ivory Coast, Forêt de l'Abouabou, between Abidjan and Grand Bassam, alt. $2 \mathrm{~m}$, white sandy soil, $5^{\circ} 14^{\prime} \mathrm{N}, 3^{\circ} 53^{\prime} \mathrm{W}$, fr. 1 Aug. 1970, Leeuwenberg 8026 (holotype K!, isotypes UPS, WAG image!).

http://www.ipni.org/urn:lsid:ipni.org:names:60477042-2

Evergreen shrub or climber c. $3 \mathrm{~m}$ tall. Bark grey. Brachyblasts (short plagiotropic shoots or spur-shoots) ascending. Leafy stems terete, drying black-brown in the distal internodes which are $(2.3-) 2.7-3.5(-4.2) \mathrm{cm}$ long; epidermis below the seventh internode from the apex glossy pale brown, with darker longitudinal fissures, internodes $(0.2-) 0.3(-0.4) \mathrm{cm}$ wide. Leaves drying black, dark green and slightly shining when live (Leeuwenberg 2659) distichous, not dimorphic, opposite and equal both at each node and between nodes, glabrous apart from the domatia; blades drying black on both surfaces, coriaceous, oblong-elliptic, (5.8-) 6.6 $8.7(-9.7) \times(2.2-) 2.7-4(-4.3) \mathrm{cm}$, apex $(0.3-) 0.6-$ $1 \mathrm{~cm}$ long; secondary nerves (3-) 4-5 (-6) on each side of the midrib, departing at c. $45^{\circ}$, rising steadily, the distal-most nerves sometimes joining the nerves above, forming a looping inframarginal nerve. Tertiary nerves mostly inconspicuous. Domatia obovate-oblanceolate, inserted in the angle between secondary nerve and midrib, c. $0.75 \times 0.5 \mathrm{~mm}$, the aperture occluded by $10-$ 50 copper-coloured hairs inserted at the margin and directed towards the centre, each c. $0.25 \mathrm{~mm}$ long; petiole shallowly canaliculate along its length, not winged, $(0.4-) 0.7-1.1 \mathrm{~cm}$ long, c. $0.1 \mathrm{~cm}$ wide. Interpetiolar stipules $(2.5-) 3(-3.5) \times 2(-3.5) \mathrm{mm}$, persisting $3-4$ nodes below apex, shortly sheathing (sheath $0.5-0.6 \times 2(-3.5) \mathrm{mm}$ ), limb triangular, often dominated by a thickened arista $(1.5-) 2.5 \times 0.35 \mathrm{~mm}$. Inflorescences 6 - 18-flowered, axillary, in both axils of \pm four successive nodes, initials appearing in the second node from the apex, glabrous. Post-anthetic inflorescences with all axes glabrous, peduncle $2-4 \mathrm{~mm}$ long, naked, the peduncle apex dividing into two 

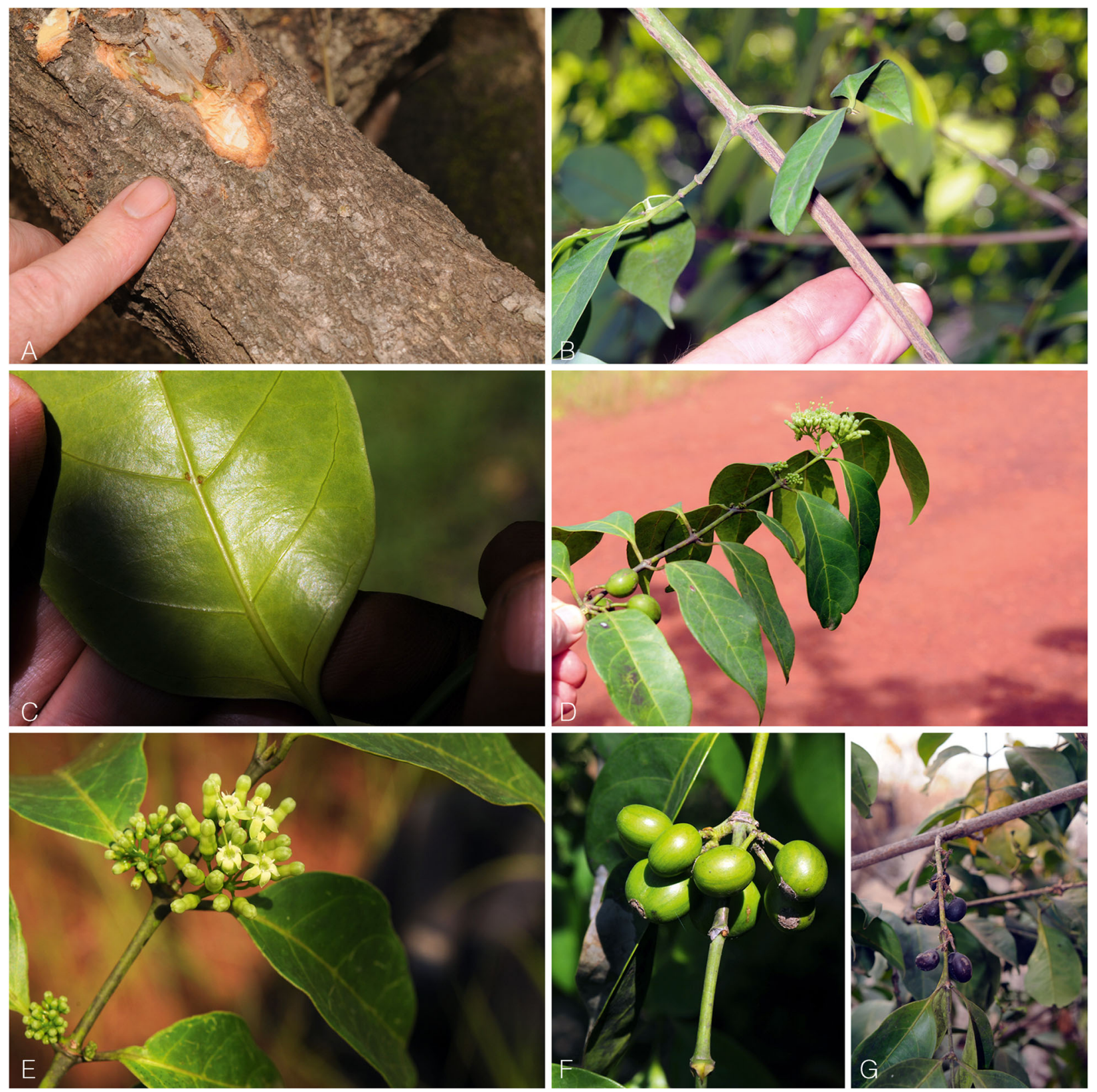

Fig. 3. Keetia susu. A trunk; B reflexed, climbing, brachyblasts (short plagiotropic or spur shoots); C lower surface of blade showing domatia; D flowering and fruiting plagiotropic shoot; $\mathbf{E}$ detail of inflorescence at anthesis; $\mathrm{F}$ 1-seeded and 2-seeded fruits, immature; G branch, with mature (black) fruits. A - C, F from Cheek 18521; D \& E from Cheek 18644; G from Cheek 18327. PHOTOS: MARTIN CHEEK.

equal bracteate branches $2.5-4 \mathrm{~mm}$ long. Bracts c. 10 , triangular-foliose, c. $1.5 \times 1.2 \mathrm{~mm}$ (decreasing in size towards branch apices) subtending the pedicels. Pedicels $0.6-0.8 \mathrm{~cm}$ long, terete. Calyx (postanthetic) tube $0.25-0.3 \mathrm{~mm}$ long, c. $1.5 \mathrm{~mm}$ wide, teeth 5 , triangular-rounded, $0.1-0.3 \mathrm{~mm}$ long and wide, each with $4-5$ hairs $0.1 \mathrm{~mm}$ long at apex. Disc flattened-rounded, $0.1 \mathrm{~mm}$ long, $1.5 \mathrm{~mm}$ wide, hairs as calyx. Drupe drying glossy black (2-seeded fruit) bilaterally symmetric, $15 \times 15-16 \times 8 \mathrm{~mm}$ (when dried), the apex truncate, disc accrescent, elliptic $8 \times$ $5 \mathrm{~mm}$, pale grey, corky, calyx absent, base rounded, widest side with a shallow groove between the carpels; 1-seeded fruit asymmetric, $14 \times 10 \times 8 \mathrm{~mm}$, disc $5.5 \times$ $4.5 \mathrm{~mm}$, pedicel inserted $4-5 \mathrm{~mm}$ from the base. Pedicels in fruit $7-8 \mathrm{~mm}$ long, $1 \mathrm{~mm}$ wide. Pyrene dark brown, woody, subellipsoid, $1.3 \times 0.9 \times 0.8 \mathrm{~cm}$, the surface obscurely rugose. Lid on apex, angled to ventral face at $45^{\circ}$ from horizontal, rounded-quadrate, c. $6 \times 6 \mathrm{~mm}$, upper surface convex, with an indistinct 
Table 1. Characters distinguishing Keetia susu from Keetia abouabou.

\begin{tabular}{|c|c|c|}
\hline & Keetia susu & Keetia abouabou \\
\hline Distribution & Guinea & Ivory Coast \\
\hline Habitat & sandstone table mountains; 200 - $800 \mathrm{~m}$ alt. & coastal rainforest on white sand; $2-5 \mathrm{~m}$ alt. \\
\hline Leaf petioles of principal axes & $\begin{array}{l}\text { conspicuously winged in distal quarter, } \\
\text { wings tapering abruptly }\end{array}$ & petiole not winged \\
\hline $\begin{array}{l}\text { Inflorescence axes post-anthesis } \\
\text { (with young fruit) }\end{array}$ & sparsely covered in multicellular hairs & glabrous \\
\hline Leaf-blade colour on drying & green & black \\
\hline $\begin{array}{l}\text { Domatia visible on upper blade } \\
\text { surface or not }\end{array}$ & clearly visible & not visible \\
\hline Midrib colour on drying & discolorous with blade: yellow & concolorous with blade: black \\
\hline Plagiotropic (or spur) shoots & reflexed & erect-ascending \\
\hline Leaf-blade shape & elliptic-oblong or ovate-elliptic & narrowly elliptic or oblanceolate-elliptic \\
\hline Pyrene lid & with a low, midline keel & indistinct midline ridge \\
\hline
\end{tabular}

broad midline ridge, ventral surface of pyrene with a shallow recess below the lid. Crests or other ornamentation lacking. Fig. 4.

RECOGNITION. Differs from Keetia mannii in the glabrous stems and leaves (apart from the domatia) and inflorescences (not hairy), in the glossy fruit $15 \mathrm{~mm}$ long (not matt $5-7 \mathrm{~mm}$ long) with fruit disc $5.5-$ $8 \mathrm{~mm}$ across, lacking calyx remnants (not $<1 \mathrm{~mm}$ across, enclosed by persistent calyx).

DISTRIBUTION. Ivory Coast, near Abidjan on the road for Grand Bassam. Map 1.

SPECIMENS EXAMINED. IVORY COAST. Forêt de l'Abouabou, between Abidjan and Grand Bassam, old fl., 4 Feb. 1959, Leeuwenberg 2659 (BR, K!, WAG); ibid., old fl., 8 Jan. 1964, Oldeman 858 (K!, WAG); ibid. fr.. 1 Aug. 1970, Leeuwenberg 8026 (holotype K!; isotypes UPS, WAG image!).

HABITAT \& ECOLOGY. Coastal evergreen rainforest and thicket with Alchornea cordifolia (Schumach.) Müll. Arg. on white sand, altitude $2 \mathrm{~m}$.

CONSERVATION STATUS. No forest exists near the only specimen-derived grid-reference for this species $\left(5^{\circ} 14^{\prime} \mathrm{N}, 3^{\circ} 53^{\prime} \mathrm{W}\right.$ - Leeuwenberg 8026). However placing Abouabou in the search box of Google Earth gives instead a still mainly forested peninsula close to Abidjan, at $5^{\circ} 17^{\prime} 38.51 " \mathrm{~N}, 3^{\circ} 53^{\prime} 35.83^{\prime \prime} \mathrm{W}$. This location was classified as a forest reserve (Forêt Classé de l'Abouabou), of $4700 \mathrm{Ha}$ in the $1940 \mathrm{~s}$ but was declassified by government arrêté 2162 of 23

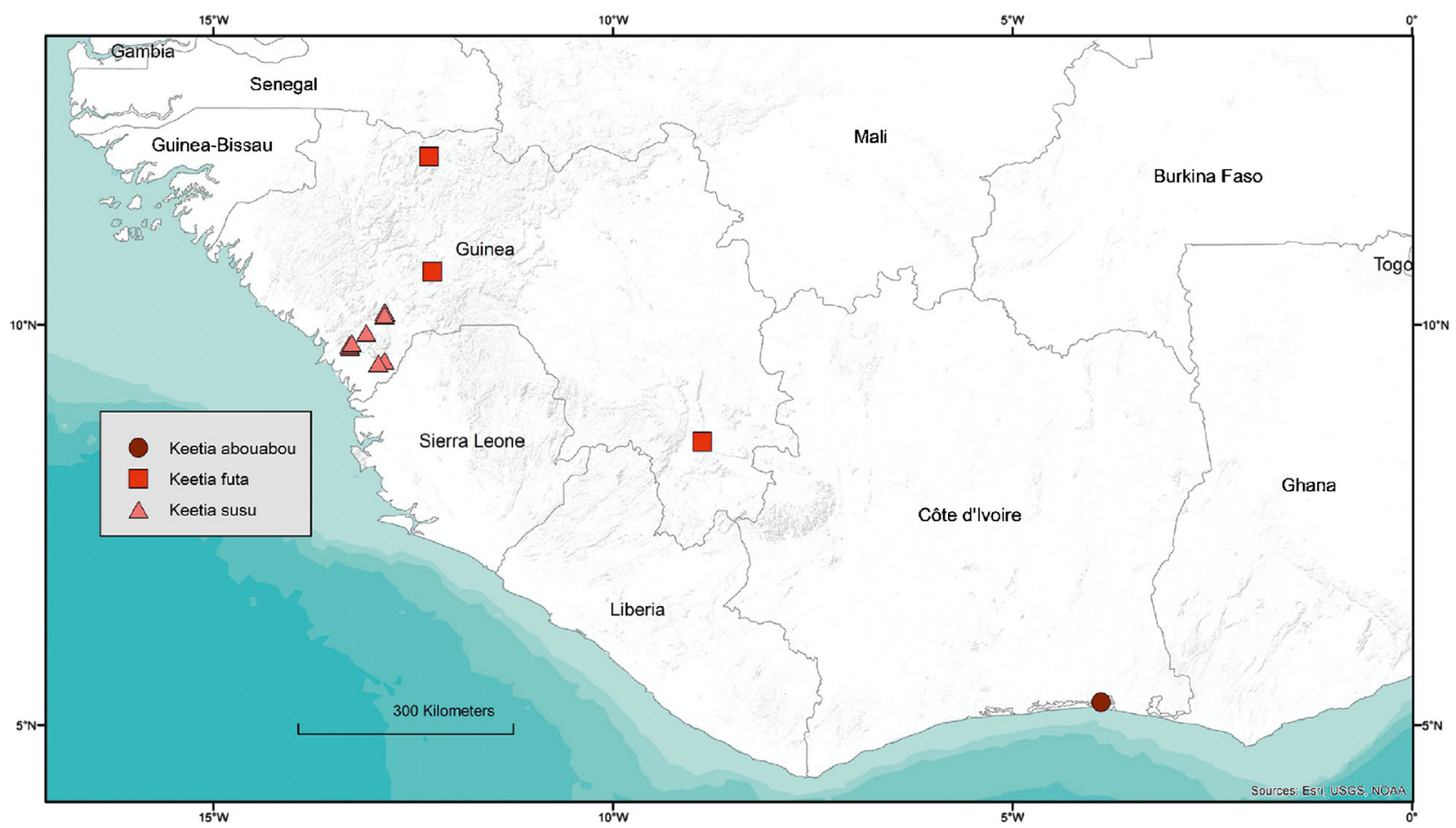

Map 1. Global distributions of Keetia abouabou, K. susu and K. futa. BY GEORGE GOSLINE. 


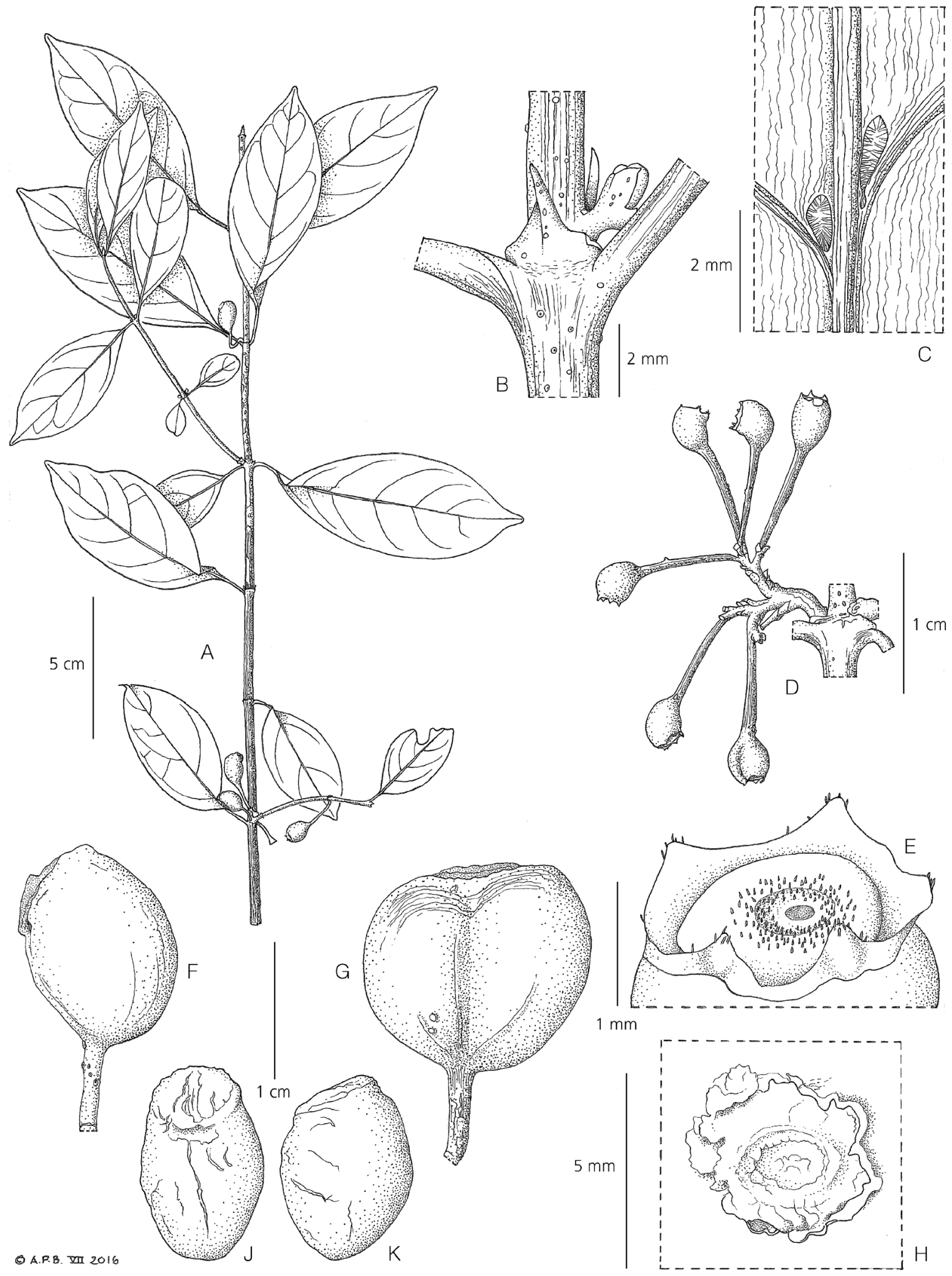

Fig. 4. Keetia abouabou. A habit, fruiting branch, note erect brachyblast; B detail of node with stipule and inflorescence initial; $C$ abaxial leaf surface showing domatia and midrib; $\mathbf{D}$ immature infructescence; $E$ apex of immature fruit, showing the hairy disc and calyx lobes; F 1-seeded fruit, side view; $\mathbf{G}$ 2-seeded fruit, side view; $\mathrm{H}$ apex of mature fruit showing the large, accrescent disc; J pyrene, ventral view, showing the apical lid; K pyrene, side view. A from Oldeman 858; B, C, F - K from Leeuwenberg 8026; D, E from Leeuwenberg 2659. DRAWN BY ANDREW BROWN. 
March 1955 (Makre 2015). The forest of Abouabou is now mainly divided into plots for house-building, although parts of the peninsula to the East have been planted with oil palm (observed using Digital Globe Imagery date 1/6/2016 viewed March 2017 on Google Earth). A series of articles in the newspapers Notre Voie (Abidjan) and also Le Debate Ivoirien tell the story of Abouabou. An overview is given by Makre (2015) in the second of these publications. He explains that control of the development of the declassified forest of Abouabou has been the subject of ongoing dispute between the national authorities and five villages that claim the land as theirs. This dispute has continued for several years, and is ongoing (Kei 2017). Were it not for the dispute, it is quite possible that the house lots would have been developed by now and the species lost.

An article on Arbitrary evictions in Protected Forests dated 13 June 2016 (https://www.hrw.org/ news / 2016/06/13/cote-divoire-arbitrary-evictionsprotected-forests) gives national context. It explains that during the recent years of insecurity, large number of people moved into many of Ivory Coast's 231 Forêt Classé and began clearing forest and cultivating crops, to the extent that many such forests have now largely been replaced by farmland.

Given these factors, using the Categories \& Criteria of IUCN (2012) we assess the conservation status of Keetia abouabou as Critically Endangered, CR $\mathrm{B} 1+\mathrm{B} 2 \mathrm{ab}$ (iii) (if it is not already extinct) since it is known only from a single location, the forest of Abouabou, which is showing steady contraction and degradation, apparently due to urbanisation pressures from Abidjan (see below). Within this location, for as long as it continues to survive, it may not be rare so long as its habitat survives since three specimens have been collected there by visiting Dutch botanists (in 1959, 1964 and 1970). The extent of Occurrence (EOO) is estimated from the approximate area of the surviving forest-scrub habitat at the location as being c. $6 \mathrm{~km}^{2}$ using Google Earth imagery from Digital Globe dated 1/6/2016, downloaded 4 Jan. 2018.

It is advisable that surveys are conducted to obtain baseline information on the survival of Keetia abouabou, such as the number and precise location of mature individuals (if any survive), and that the regeneration levels are assessed, so that future monitoring can be put in place. A publicity campaign with the aim of raising awareness of the uniqueness of this species and of its threats, might help to reduce habitat degradation as its only known site, or to gain support for setting aside an area where natural habitat including this unique species might be preserved. Surveys of other areas of coastal forest on white sand in Ivory Coast are advisable to discover if the species has a wider range than is currently evidenced. It is to be hoped that additional, less threatened locations might be found. Potential areas where the species might still be found are at $5^{\circ} 14^{\prime} 52.99^{\prime \prime} \mathrm{N}, 3^{\circ} 48^{\prime} 51.77^{\prime \prime} \mathrm{W}$ and at $5^{\circ} 13^{\prime} 26.67^{\prime \prime} \mathrm{N}, 3^{\circ} 48^{\prime} 20.27^{\prime \prime} \mathrm{W}$, based on observations made by the first author using Google Earth. However, it is possible that this species is a point-endemic as is $K$. bakossiorum Cheek of Cameroon which has also been assessed as Critically Endangered (Onana \& Cheek 2011: 275).

ETYMOLOGY. The species is named for its type and only known location, the former Forêt Classé de l'Abouabou, now in the process of becoming a residential district of Abidjan.

NOTES. Bridson annotated a species cover (specimen folder) of three specimens at Kew as: "sp = Leeuwenberg 8026 etc. (fruit larger than in mannii group)", and annotated Leeuwenberg 8026 as: "Keetia sp. = Leeuwenberg 2659 and Oldeman 858". These three specimens, all at different stages, originate from the Forêt d'Abouabou of Côte D'Ivoire, on the southern edge of Abidjan en route for Grand Bassam. These specimens differ from K. mannii in several additional characters apart from the large fruit size, such as the massive fruit disc, the glabrous leaves and stems, and in the few-flowered, open inflorescences. These and other diagnostic characters indicated in Table 1, amply justify recognising and describing this species, first segregated by Bridson, as new to science. Formal naming of this species has some urgency, since its white sand thicket-forest habitat near Abidjan appears to be fast disappearing (see below). None of the known specimens of this species are cited in the Flore de Côte D'Ivoire (Ake Assi 2001a, 2001b) nor are any other specimens of the Keetia cited in that work collected from Abouabou.

WHITE SAND HABITAT. The habitat of Keetia abouabou appears to be the result of long-shore drift or wind-blown sand. Sand carried and deposited by the sea over aeons has formed almost continuous sandbars along the coast, resulting in narrow coastal lagoons between the linear sandbars and the more ragged original coastline. Such coastal white sand habitats in Africa and Madagascar not uncommonly host distinctive vegetation types and plant species which are entirely restricted to them, such as Baphia vili Cheek and other species in the coastal white sands of Congo-Brazzaville and Gabon (Cheek et al. 2014). Additional white sand habitats with unique species such as Baphia madagascariensis C. H. Stirt. \& Du Puy, occur in NW Madagascar (Stirton \& Du Puy 1992). Further coastal sand habitats in Africa with unique species are the sand forests of KwaZulu Natal (including Warneckea parvifolia R. D. Stone \& Ntetha (2013) and Cola dorrii Cheek in Cheek et al. 2018a) and northern Mozambique (Timberlake et al. 2011; Johnson et al. 2017). Typically these white sand vegetation types of thicket or low forest are rapidly denuded of any sizeable 
trees that they may have had when they are close to ports and settlements. Their soils being too impoverished for crops, they can otherwise remain more or less intact. White sand vegetation is overlooked by botanical collectors despite being accessible, since it can appear degraded, secondary and thicket-like. As port cities such as Abidjan and Pointe Noire expand along the coast, this habitat is rapidly being totally removed due to urbanisation, increased port and industrial facilities, and tourism installations (Cheek et al. 2013; Gosline et al. 2014). As the habitat disappears, so do the plant species which are unique to it, such as apparently, K. abouabou. It is greatly to the credit of Leeuwenberg and Oldeman that they did not ignore this vegetation type in Ivory Coast, otherwise $K$. abouabou might have become extinct without ever having been discovered by science. Yet who knows how comprehensive their collections were, and what other white-sand specific species there might be (or have been) that accompany it, and remain uncollected as herbarium specimens and so are still unknown to science?

Keetia futa Cheek sp. nov. Type: Guinea (GuineaConakry), Simandou Range, Pic de Dabatini, au nord $\mathrm{du}$ Pic de Fon, Galerie forestiere, 8'33'16”N, 8`53'12"W, $1008 \mathrm{~m}$, immature fr., 23 March 2008, P. K. Haba 179 (holotype HNG !; isotypes $\mathrm{K}$ !,WAG!).

http:/ /www.ipni.org/urn:lsid:ipni.org:names:60477043-2

Canthium rubens sensu Hepper, non Hiern, quoad Jacques-Félix 2061 \& Roberty 16566 (Hepper 1963: 184).

Keetia molundensis (K. Krause) Bridson pro parte (Bridson 1986: 976).

Evergreen (probably) climber to $10 \mathrm{~m}$ long (P. K. Haba 179), stems terete, $2-4(-5) \mathrm{mm}$ diam., internodes $(1.4$ -) 3 - 5.6 (- 6.4) cm long, red-brown, indumentum moderately dense, hairs red, patent $0.2 \mathrm{~mm}$ long on the distal internodes. Leaves opposite, chartaceous, equal, distichous, slightly dimorphic (see below), leaves of the principal axis ovate-oblong, base cordate; leaves of the plagiotropic branches elliptic-oblong or obovate-elliptic, base rounded, (2-) 5.9-9.2 (-11.6) × (1.8-) $2.7-4.3$ ($5.1) \mathrm{cm}$, apex shortly acuminate, the acumen apex rounded, $0.2-0.8(-1.5) \mathrm{cm}$, secondary nerves $4-6$ (8) on each side of the midrib, nerves departing the midrib at $45-80^{\circ}$, arching up towards the leaf apex; towards the margin uniting with a series of tertiary nerves from the secondary nerve above, forming a weak and incomplete looping marginal nerve; tertiary nerves branching, conspicuous, irregular, connecting the secondary nerves along much of their length; quaternary nerves inconspicuous. Domatia absent. Hairs moderately dense on upper and lower surface, hairs curved to sinuous, red, tapering to apex from a thick base, on the adaxial midrib 1.5 - $2 \mathrm{~mm}$ long, more or less appressed, those of the abaxial midrib $1.5-3 \mathrm{~mm}$ long, spreading, the areolae with hairs $1-2$ per $\mathrm{mm}^{2}, 0.5-1 \mathrm{~mm}$ long. Petiole canaliculate, $0.5-1.1(-1.8) \mathrm{cm}$ long, indumentum as stem. Stipules persistent, ovate $1.8-2 \times$ $1-1.2 \mathrm{~cm}$, lacking keel or arista, glabrescent. Inflorescences (Fig. 5B), axillary on principal axis and short plagiotropic branches, in $2-3$ successive nodes beginning c. 3 nodes below stem apex; anthesis \pm simultaneously in most of the flowers in an inflorescence, each 20 - 40-flowered, forming heads c. $3 \mathrm{~cm}$ diam. Peduncles $12-15 \mathrm{~mm}$, with a pair of ovatetriangular, bracts near apex, bracts c. $8 \times 5 \mathrm{~mm}$, flat, more or less caducous; branches two, equal, $2-7 \mathrm{~mm}$ long, with $2-3$ pairs of subapical bracteoles c. $2 / 5$ the size of the bracts, each branch sometimes further forked. Inflorescences 1 - 3-fruited, axes glabrescent. Flowers with pedicels $6-9 \mathrm{~mm}$ long, moderately densely hairy, hairs erect, curved, $0.3 \mathrm{~mm}$ long at anthesis. Calyxhypanthium, in bud, obconical c. $2.5 \times 2.5 \mathrm{~mm}$, the tube $1.5 \times 1.5 \mathrm{~mm}$, the lobes triangular $0.8-1.1 \times 0.8-1.1$ $\mathrm{mm}$, apex acute; at anthesis shortly cylindric $2.5-3.1 \times$ $2.1-2.5 \mathrm{~mm}$, indumentum as the leaves, dense, obscuring the surface at the base of the tube, and on the lobes, including the inner surface at the lobe apices and bases along the midline. Corolla white, glabrous in bud, the proximal part narrowly cylindrical, $2-3 \times 0.5$ $\mathrm{mm}$, the apex capitate, globose c. $1.7 \mathrm{~mm}$ diam.; at anthesis cylindric c. $3.5 \times 2.5 \mathrm{~cm}$; lobes 5 , oblong-elliptic, strongly reflexed, $3 \times 1.2-1.4 \mathrm{~mm}$, margins increasingly involute towards apex, the apex slightly hooded; inner surface glabrous. Stamens inserted just below apex of tube, filaments $0.3-0.4 \mathrm{~mm}$ long; anthers sub-basifixed, elliptic, $1.4-1.5 \times 0.7 \mathrm{~mm}$, lacking apiculus, base shortly bifurcate. Disc shortly conicalconvex, hairy at apex around style base, hairs $0.05-$ $0.15 \mathrm{~mm}$ long, erect. Style $7-8 \times 0.15 \mathrm{~mm}$, glabrous; head cylindric, bilobed, about twice as long as broad, $1.1-1.3 \mathrm{~mm}$ long, outer surface densely papillate. Infructescences (immature), 1 - 4-fruited, only 1-seeded fruits seen, pedicels $0.9-1.2 \mathrm{~cm}$ long. Fruit (immature), strongly asymmetric ellipsoid, $1.2-1.5 \times 0.8-1$ $\mathrm{cm}$, the pedicel inserted at c. $90^{\circ}$ to the axis of the calyx), sparsely hairy, the hairs c. $1 \mathrm{~mm}$ long, densest near the calyx; fruiting calyx persistent, not accrescent, $2 \times 2 \mathrm{~mm}$. Pyrene and seed not available. Fig. 5

RECOGNITION. Similar to Keetia molundensis (K. Krause) Bridson, but calyx with well-developed teeth (calyx limb not truncate to repand), pedicels $6-9 \mathrm{~mm}$ long (not $3-5 \mathrm{~mm}$ long) and stem rusty-red tomentose (not glabrous or setose).

DISTRIBUTION. Known only from the Guinea Highlands of Guinea. Map 1. 


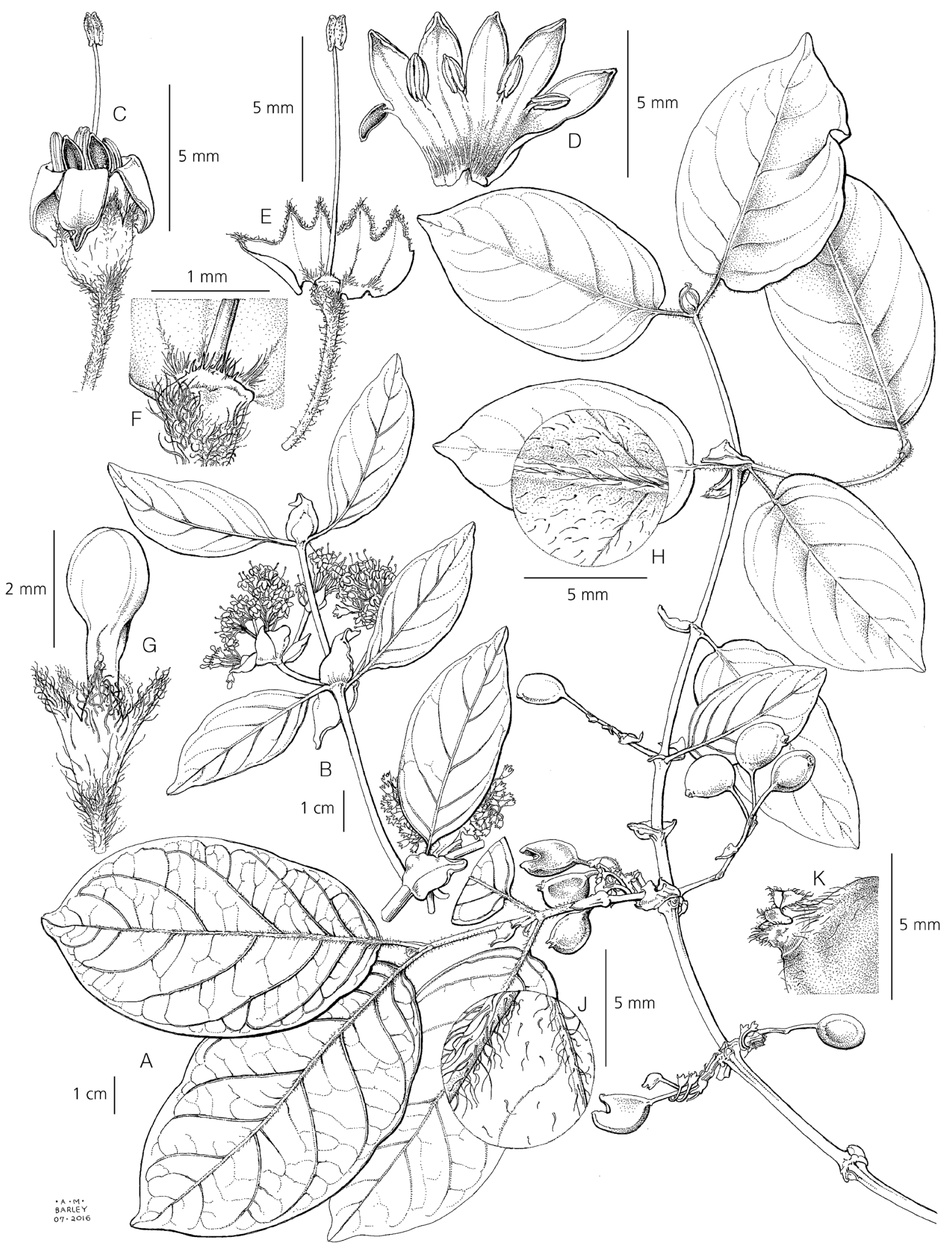

Fig. 5. Keetia futa. A habit, fruiting stem; B flowering stem; C flower at anthesis, side view; D corolla from C opened out to show inner surface; E flower at anthesis, corolla removed, calyx opened to show inner surface, style base, and disc; F detail of E showing hypanthium and disc; $\mathrm{G}$ flower bud; $\mathrm{H}$ detail of $\mathrm{A}$, showing indumentum, adaxial leaf-blade; J detail from $\mathrm{A}$ showing indumentum of abaxial leafblade; $\mathrm{K}$ detail of immature fruit apex. A, H-K from P. K. Haba 179; B - G, J from Jacques-Félix 2061. DRAWN BY ANITA BARLEY. 
SPECIMENS EXAMINED. GUINÉE (CONAKRY). Environs de Diaguissa, fl., Oct. 1937, Jacques-Félix 2061 (K!, P); Mali, fl., 18 Jan. 1955, G. Roberty 16566 (K!); Simandou, Mt Simandou, Pic de Dabatini, au nord $\mathrm{du}$ Pic de Fon, Galerie forestiere, 8³3'16”N, 8 53'12”W, 1008 m, fr., 23 March 2008, P. K. Haba 179 (HNG, K!, WAG!).

HABITAT \& ECOLOGY. Submontane evergreen (cloud) forest $900-1000 \mathrm{~m}$ altitude.

CONSERVATION STATUS. Keetia futa appears to be very rare within its large range (extent of occurrence) which was calculated with Geocat as $31,839.651 \mathrm{~km}^{2}$. The most recent specimen, $P$. K. Haba 179 is from the Simandou Range, where, between 2005 and 2012, 3882 specimens were collected as part of an Environmental Impact Assessment for an intended open-cast iron ore mine, then planned by the company Rio Tinto. However, despite this collection effort, only a single specimen of this species was found. The Dabatini area, the site of P. K. Haba 179 was earmarked as a conservation area by Rio Tinto. Now (2017) that the control of that project has passed to Chinalco, there is uncertainty as to whether former plans will remain unmodified or not, and so we consider that this species may now be at risk at this site. Our observations in 2016 - 2017 of the surviving submontane forest in the Futa Djalon shows that the remaining forest patches are already heavily degraded for timber and other products. Despite our targeted searches in these habitats in the Futa for this species in 2016 and 2017, we failed to find it and conclude that it is very infrequent and possibly locally extinct there. Here we assess Keetia futa as Endangered, EN B2ab(iii) since at each of the three sites known (equating to three IUCN locations), threats are present as documented above. We calculate the area of occurrence (AOO) as $12 \mathrm{~km}^{2}$ using the $4 \mathrm{~km}^{2}$ cell size preferred by IUCN (2012).

ETYMOLOGY. Signifying from the Futa Djalon Highlands (also known as 'Fouta Djallon', or 'Futa') as a noun in apposition. The first known specimens of this taxon were collected there.

NOTES. In her footnotes to her account of Keetia molundensis (K. Krause) Bridson, Bridson (1986: 976) states: "Two specimens from Guinea, Jacques-Felix 2061 \& Roberty 16566, cited in Fl. Trop. W. Afr. ed.2, 2: 184 (1963) as belonging to Canthium rubens are very close to the above species and could be recognised either as a subspecies or separate species. They differ from $K$. molundensis in the young stems having rusty-red tomentose hairs, calyx-limb with well-defined teeth and pedicels $6-8 \mathrm{~mm}$ long (as opposed to young stems glabrous to densely setose; calyx-limb truncate to repand; pedicels 3 - 5 mm long)." Hepper (1963: 184) in citing those two specimens had also indicated that they "may be specifically distinct from the true
C. rubens". Both these specimens originate from submontane forest of the Fouta Djalon in Guinea. Subsequently a third specimen, $P$. K. Haba 179, conspecific with the first two specimens, was collected from submontane forest in the Simandou Range of the LomaMan Highlands of Guinea. Diagnostic characters separating this new taxon, here named as Keeta futa, from K. molundensis, are detailed under "RECOGNITION" above. These are sufficient to recognise it as a new species

Keetia futa is one of several new species to science that came to light partly or entirely as a result of environmental impact assessment studies in connection with the Simandou Range. Others are Brachystephanus oreacanthus Champl. (Acanthaceae) (Champluvier \& Darbyshire 2009), Eriosema triformum Burgt (Leguminosae) (van der Burgt et al. 2012), Gymnosiphon samoritoureanus Cheek (Burmanniaceae) (Cheek \& van der Burgt (2010), Psychotria samoritourei Cheek (Rubiaceae) (Cheek \& Williams 2016), Striga magnibracteata Eb. Fisch. \& I. Darbysh. (Orobanchaceae) (Fischer et al. 2011) and Xysmalobium samouritourei Goyder (Apocynaceae) (Goyder 2009).

\section{Acknowledgements}

Professor Basile Camara, former Director General, Université de Gamal Abdel Nasser-Herbier National de Guinée, is thanked for arranging permits and for long term support and collaboration. Janis Shillito is thanked for typing the manuscript. Some of the measurements for this paper were made by citizen scientists at the Kew Science Festival in August 2016. This paper was completed under the project Important Plant Areas in the Republic of Guinea supported by the Darwin Initiative of the Department of the Environment Food and Rural Affairs (DEFRA), UK government (project Ref. 23 - 002). Diane Bridson and an anonymous reviewer are thanked for constructive comments on an earlier draft of the paper.

Open Access This article is distributed under the terms of the Creative Commons Attribution 4.0 International License (http://creativecommons.org/licenses/by/ $4.0 /$ ), which permits unrestricted use, distribution, and reproduction in any medium, provided you give appropriate credit to the original author(s) and the source, provide a link to the Creative Commons license, and indicate if changes were made.

\section{References}

Aké Assi, L. (2001a). Flore de la Côte-d'Ivoire: catalogue systématique, biogéographie et écologie. I. Boissiera 57. (2001b). Flore de la Côte-d'Ivoire: catalogue systématique, biogéographie et écologie. II. Boissiera 58. 
Bachman, S., Moat, J., Hill, A. V., De la Torre, J. \& Scott, B. (2011). Supporting Red List threat assessments with GeoCAT, a geospatial conservation assessment tool. Zookeys 150: $117-126$.

Bridson, D. M. (1985). The reinstatement of Psydrax (Rubiaceae, subfam. Cinchonoideae tribe Vanguerieae) and a revision of the African species. Kew Bull. 40: 687 - 725.

(1986). The Reinstatement of the African genus Keetia (Rubiaceae, Cinchonoideae, Vanguerieae). Kew Bull. 41: 956 - 994.

(1994). A new species of Keetia (RubiaceaeVanguerieae). Kew Bull. 49: 803 - 807.

(1998). Rubiaceae (Tribe Vanguerieae). In: G. V. Pope (ed.), Flora Zambesiaca 5 (2): 1 - 377. Royal Botanic Gardens, Kew for the Flora Zambesiaca Managing Committee.

\& Robbrecht, E. (1993). A spiny-fruited new Keetia (Rubiaceae, Vanguerieae) from Kivu (Zaire). Belg. J. Bot. 126: 29 - 32.

\& Verdcourt, B. (1991). Flora of Tropical East AfricaRubiaceae, 3. A. A, Balkema, Rotterdam/Brookfield.

van der Burgt, X. M., Haba, P. K., Haba, P. M. \& Goman, A. S. (2012). Eriosema triformum (Leguminosae: Papilionoideae), a new unifoliolate species from Guinea, West Africa. Kew Bull. 67: 263 271. https://doi.org/10.1007/s12225-012-9357-5.

Molmou, D., Diallo, A., Konomou, G., Haba, P.

K. \& Magassouba, S. (2018). Talbotiella cheekii (Leguminosae: Detarioideae), a new tree species from Guinea. Kew Bull. 73: 26. https://doi.org/ 10.1007/s12225-018-9755-4.

Champluvier, D. \& Darbyshire, I. (2009). A revision of the genera Brachystephanus and Oreacanthus (Acanthaceae) in tropical Africa. Syst. E Geogr. Pl. $79(2): 115-192$.

Cheek, M. (2006). A New Species of Keetia (RubiaceaeVanguerieae) from Western Cameroon. Kew Bull. 61: $591-594$.

\& Ameka, G. (2016). Macropodiella cussetiana (Podostemaceae) a new species from Côte d'Ivoire. Kew Bull. 71: 21. https://doi.org/10.1007/S12225016-9634-9.

\& van der Burgt, X. (2010). Gymnosiphon samoritoureanus (Burmanniaceae) a new species from Guinea, with new records of other achlorophyllous heteromycotrophs. Kew Bull. 65: 83 - 88. https:// doi.org/10.1007/s12225-010-9180-9.

Challen, G., Lebbie, A., Banks, H., Barberá, P. \& Riina, R. (2016). Discovering Karima (Euphorbiaceae) a New Crotonoid Genus from West Tropical Africa Long Hidden within Croton. PLoS ONE 11(4): e0152110. https://doi.org/ 10.1371/journal.pone.0152110.

\& Haba, P. (2016). Inversodicraea Engl. resurrected and I. pepehabai sp. nov. (Podostemaceae), a submontane forest species from the Republic of
Guinea. Kew Bull. 71: 55. https://doi.org/10.1007/ S12225-016-9673-2.

Kami, E. \& Kami, T. (2014). Baphia vili sp. nov. (Leguminosae-Papilionoideae) of coastal thicket of the Congo Republic and Gabon. Willdenowia 44: 39 44. https://doi.org/10.3372/wi.44.44106.

, Lawrence, P. \& McCleland, W. (2018a). Cola dorrii sp. nov. (Sterculiaceae) a threatened Maputaland Forest endemic of South Africa. Kew Bull. 73: 25. https://doi.org/10.1007/s12225-018-9749-2.

\& Luke, Q. (2016). Calophyllum (Clusiaceae Guttiferae) in Africa. Kew Bull. 17: 2. https:// doi.org/10.1007/S12225-016-9637-6.

, Magassouba, S., Howes, M. R., Doré, T., Doumbouya, S., Molmou, D., Grall, A., Couch, C. \& Larridon, I. (2018b). Kindia (Pavetteae, Rubiaceae), a new cliffdwelling genus with chemically profiled colleter exudate from Mt Gangan, Republic of Guinea. PeerJ 6: e4666. https://doi.org/10.7717/peerj.4666.

\& Williams, T. (2016). Psychotria samoritourei (Rubiaceae), a new liana species from Loma-Man in Upper Guinea, West Africa. Kew Bull. 71: 19. https://doi.org/10.1007/S12225-016-9638-5.

Darbyshire, I. (continuously updated). Tropical Important Plant Areas. http://science.kew.org/strategic-output/tropical-important-plant-areas

, Anderson, S., Asatryan, A., Byfield, A., Cheek, M., Clubbe, C., Ghrabi, Z., Harris, T., Heatubun, C. D., Kalema, J., Magassouba, S., McCarthy, B., Milliken, W., de Montmollin, B., Nic Lughadha, E., Onana, J. M., Saidou, D., Sarbu, A., Shrestha, K. \& Radford, E. A. (2017). Important Plant Areas: revised selection criteria for a global approach to plant conservation. Biodivers. Conserv. 26: 1767 - 1800. https://doi.org/ 10.1007/s10531-017-1336-6.

Fischer, E., Darbyshire, I. \& Cheek, M. (2011). Striga magnibracteata (Orobanchaceae) a new species from Guinée and Mali. Kew Bull. 66: 441 - 445. https:// doi.org/10.1007/s12225-011-9296-6.

Goyder, D. J. (2009). Xysmalobium samoritourei (Apocynaceae: Asclepiadoideae), a new species from the Guinea Highlands of West Africa. Kew Bull. 63: 473 - 475. https://doi.org/10.1007/ s12225-008-9059-1.

Gosline, G., Cheek, M. \& Kami, T. (2014). Two new African species of Salacia (Salacioideae, Celastraceae). Blumea 59: 26 - 32.

Hawthorne, W. \& Jongkind, C. (2006). Woody Plants of Western African Forests: A guide to the forest trees, shrubs and lianes from Senegal to Ghana. Royal Botanic Gardens, Kew.

Hepper, F. N. (1963). Canthium. In: F. N. Hepper \& R. W. J. Keay (eds), Flora of West Tropical Africa, Vol. 2: 180 - 185. Crown Agents, London.

The International Plant Names Index (continuously updated). http://ipni.org/. (accessed: 01/2017). 
IUCN (2012). IUCN Red List Categories and Criteria: version 3.1. Second edition. Gland and Cambridge. http://www.iucnredlist.org/ (accessed: 01/2017).

Johnson, D. M., Luke, Q., Goyder, D. J. \& Murray, N. A. (2017). Four new species of Xylopia (Annonaceae) from East Africa. Kew Bull. 72(11): 1 - 13. https:// doi.org/10.1007/S12225-017-9681-X.

Jongkind, C. H. (2002). Two New Species of Keetia (Rubiaceae) from West Africa. Kew Bull. 57: 989 - 992.

Kei, D. (2017). Conflit foncier à Abouabou: 5 villages réclament la délocalisation du Cnra. Notre Voie (Abidjan). http://news.abidjan.net/h/618881.html (accessed 30 Dec. 2017)

Lachenaud, O., Luke, Q. \& Bytebier, B. (2017). Keetia namoyae (Rubiaceae, Vanguerieae), a new species from eastern Democratic Republic of Congo. Candollea 72: 23 - 26.

Lantz, H. \& Bremer, B. (2004). Phylogeny inferred from morphology and DNA data: characterizing well-supported groups in Vanguerieae (Rubiaceae). Bot. J. Linn. Soc. 146: 257 - 283.

Lisowski, S. (2009). Flore (Angiospermes) de la République de Guinée. Scripta Bot. Belg. 41. National Botanic Garden of Belgium.

Makre, H. (2015). http://www.ledebativoirien.net/ 2015/12/22/ cote-divoire-incroyable-un-villagevendu-avec-tout-son-contenu-enfants-femmeshommes-terres-maisons-tout-a-un-operateureconomique-par-le-ministere-de-la-construction-ledistrict/ downloaded 30 Dec. 2017.

Onana, J.-M. \& Cheek, M. (2011). Red Data Book, of the Flowering Plants of Cameroon: IUCN Global Assessments. Royal Botanic Gardens, Kew.
Phillips, S. M. \& Mesterházy, A. (2015). Revision of small ephemeral species of Eriocaulon (Eriocaulaceae) in West Africa with long involucral bracts. Kew Bull. 70: 5.

, Fofana, F. \& Cheek, M. (2018). Mesanthemum tuberosum Lecomte resurrected from $M$. prescottianum (Bong.) Körn. (Eriocaulaceae), variation and lectotypification. Kew Bull. 73: 13. https://doi.org/ 10.1007/s12225-018-9744-7.

Prance, G. T. \& Jongkind, C. C. H. (2015). A revision of African Lecythidaceae. Kew Bull. 70: 6. https:// doi.org/10.1007/s12225-014-9547-4.

Stirton, C. H. \& Du Puy, D. J. (1992). A new species of Baphia (Leguminosae: Papilionoideae) from Madagascar. Kew Bull. 47: 289.

Stone, R. D. \& Ntetha, N. A. (2013). Warneckea parvifolia (Melastomataceae-Olisbeoideae), a new "sand-forest" endemic from northeastern KwaZulu-Natal (South Africa) and southernmost Mozambique, and a phylogenetic analysis of eastern and southern African representatives of W. section Warneckea. S. African J. Bot. 88: 317 325 .

Thiers, B. (continuously updated). Index Herbariorum: A global directory of public herbaria and associated staff. New York Botanical Garden's Virtual Herbarium. http://sweetgum.nybg.org/ih/ (accessed: 01/ 2017).

Timberlake, J., Goyder, D., Crawford, F., Burrows, J., Clarke, G. P., Luke, Q., Matimele, H., Müller, T., Pascal, O., de Sousa, C. \& Alves, T. (2011). Coastal dry forests in northern Mozambique. Pl. Ecol. Evol. 144: $126-137$. 